\title{
The Influence of Availability of Muslim Friendly Facilities towards Indonesian Muslim Tourist Revisit Intention to Japan
}

\author{
Dina Hariani ${ }^{*}$, Myrza Rahmanita $^{2}$, Rahmat Ingkadijaya ${ }^{3}$ \\ ${ }^{1}$ Bogor Hotel Institute \\ 2,3Sekolah Tinggi Pariwisata Trisakti \\ *dinahariani03@gmail.com
}

\begin{abstract}
As the market of halal tourism destinations has increasingly become more competitive, the revisit intention topic has progressively become prominent to emphasize on. This research is designed to find out how much influence of the availability of Muslim-friendly facilities to Indonesian Muslim tourist to revisit intention to Japan. The methodology of this research is quantitative descriptive research in which questionnaire is the major tool in collected the primary data for analysis. The total sample of 100 Indonesian Muslim tourist is obtained for the analysis. The simple and multiple regression analysis are adopted to examine the key factors which significantly predict the revisit intention. The results of this research indicates that Muslim-friendly facilities likes halal hotel, halal restaurant, and prayer room are positively related to the revisit intention. The biggest need of Indonesian Muslim tourist is the availabity of halal restaurants. Regarding the situation of Muslim friendly facilities in Japan, Indonesian Muslim still finds it difficult to locate the facilities despite its availability.
\end{abstract}

Keywords: muslim friendly tourism, halal hotel, halal restaurant, prayer room, revisit intention 


\section{A. Introduction}

Japan is becoming an increasingly popular destination for Muslim travellers. In a bid to attract larger numbers of Muslim travellers, Japan is restructuring its tourist industry in order to better serve the specific needs of Muslims. The importance of the Muslim travel market segment is being realised by numerous countries around the world, with many deciding to embrace Halal tourism.

According to an article on Tribunnews.com the number of tourists from Indonesia who visit Japan during the first four months in 2017 has the largest percentage increase, which is as much as $45.5 \%$ compared to tourist arrival from other countries. According to a source at the Japan National Tourism Organization (JNTO), the increase was due to the heavily promoted tourism to Japan in Indonesia as well as the promotion of low cost airfare to Japan. The number of Indonesian tourists to Japan between January - April 2017 to 121,700 people or $45.5 \%$ increase over the period of the first 4 months of last year. As one of the biggest Muslim country in the world, most of Indonesian tourist is a Muslim that have special needs compare to other tourists such as availabilities of Halal food, prayer room, and Muslim friendly hotel.

Japan's population is mostly practice Buddhism and Shinto who do not prohibit the use of pork and alcholol in cooking. Although many Japanese people eat fish and vegetables, many sauces that are used for cooking contains lard or alcohol so it is not lawful for Muslim consumption. Muslims are commanded to pray five times a day: early morning (Shubuh), noon (Dzuhur), late afternoon (Ashar), sunset (Magrib), and night (Isya'). Shalat prayer five times a day is a major obligation of a Muslim who should not be abandoned. In Islamic teachings there are some reliefs to worship for Muslims who travel such as shortening and combining prayers, performing wudhu with tayamum, delaying fasting in Ramadan, praying everywhere (may be in transport such as airplanes or trains) (Din 1982; Hashim, Murphy, and Mohammad 2006; Henderson 2009).

Based on the Global Muslim Travel Index (GMTI) 2017 in the group of Non-Organizational Overseas Organization (OIC) destinations, Japan is in 6th place while Singapore achieved 1st place for destinations followed by Thailand, England, South Africa and Hong Kong. This proves that Japan is serious in trying to provide Muslim friendly facilities to accomodate Muslim tourists that visit the country. 
Table 1. Non-OIC Countries Rank

\begin{tabular}{|c|c|c|c|c|c|c|c|c|}
\hline \multicolumn{3}{|c|}{2015} & \multicolumn{3}{c|}{2016} & \multicolumn{3}{c|}{2017} \\
\hline Peringkat & Destinasi Non-OIC & Skor & Peringkat & Destinasi Non-OIC & Skor & Peringkat & Destinasi Non-0IC & Skor \\
\hline 1 & Singapura & 65.1 & 1 & Singapura & 68.4 & 1 & Singapura & 67.3 \\
\hline 2 & Thailand & 59.2 & 2 & Thailand & 59.5 & 2 & Thailand & 61.8 \\
\hline 3 & Inggris & 55 & 3 & Inggris & 59 & 3 & Ingriis & 60 \\
\hline 4 & Afrika Selatan & 51.1 & 4 & Afrika Selatan & 53.1 & 4 & Afrika Selatan & 53.6 \\
\hline 5 & Perancis & 48.2 & 5 & Hongkong & 53 & 5 & Hongkong & 53.2 \\
\hline 6 & Belgia & 47.5 & 6 & Perancis & 51.6 & 6 & Jepang & 52.8 \\
\hline 7 & Hongkong & 47.5 & 7 & Taiwan & 50.1 & 7 & Taiwan & 52.4 \\
\hline 8 & Amerika Serikat & 47.3 & 8 & Jepang & 49.1 & 8 & Perancis & 52.1 \\
\hline 9 & Spanyol & 46.5 & 9 & Sri Lanka & 49 & 9 & Spanyol & 48.8 \\
\hline 10 & Taiwan & 46.2 & 10 & Amerika Serikat & 48.9 & 10 & Amerika Serikat & 48.6 \\
\hline
\end{tabular}

Source : Cresent Rating, 2017

The increasing number of Indonesian muslim tourists to Japan in recent times should be well-anticipated by the service providers. Indonesia, which has predominantly Muslim population, definitely needs facilities to support their needs when traveling. Will they have difficulty carrying out their obligations in a country where the majority of the population is Shinto or Buddhist?

According to the research, $69.45 \%$ agreed that they had trouble finding Halal food in Tokyo, Japan and $73.45 \%$ agreed they had difficulty finding a prayer room while in Tokyo.

This research tries to answer the following questions:

1. Do Indonesian muslims that have ever been to Japan know the availability of muslim friendly facilities?

2. What are the most important muslim friendly facility according to Muslim Indonesian tourists?

3. How influential is the availability of the muslim friendly facility to make Indonesian Muslim tourists revisit Japan?

This research can be used as a guide for Indonesian travel agents who want to make Halal tour packages to Japan, but there are some limitations of this research. First, it only discusses three main points of the needs of Muslim tourists which are hotel, restaurants, and prayer room. Then, the researcher only focuses on three the cities such as Tokyo, Osaka, and Kyoto since they are the favorite destinations for Indonesian tourists. Lastly, this research has a limited number of respondents with only 100 participants who have been to Japan in the last 5 years. The five-year duration is due to the fact that the trend of halal tourism in Japan just started to appear in the last 5 years. 


\section{B. Literature Review}

Muslim Friendly Tourism has various names like Halal Tourism, Sharia Tourism or Islamic Tourism. There are several definitions about Halal Tourism or Islamic Tourism such as "All tourism activities by Muslims that originate from Islamic motivations and are according to shariah principles." (Dr. Teoman Duman, 2011) or "As a niche market" halal friendly "tourism includes; halal hotels, halal transport (halal airlines), halal food restaurants, halal tour packages and halal finance. Therefore, halal tourism consists of different sectors which are related with each other "(Akyol and Kilinc 2014).

Halal Tourism is relatively new concept in the tourist industry, which means offering tour packages and destinations that are particularly designed to cater for Muslim needs. Halal tourism can be divided into three points as the following : hotel implementation, restaurants offering Halal foods and daily prayer time (Takumi : 2015)

Crescent Rating, is a globally recognized independent accreditation and rating standard for Muslim-friendly travel services has categorized the Muslim traveler needs into three aspects as shown in Table 2.

Table 2. Muslim Tourist Needs

\begin{tabular}{ll}
\hline Subjects & Details \\
\hline Need to have & Halal food services \\
& Prayer facilities \\
& Water usage friendly washroom \\
Good to have & Ramadhan services and facilities \\
& No non-Halal activities \\
Nice to have & Recreation services and facilities \\
\hline
\end{tabular}

Source : Cresent Rating, 2012

The concept of repurchase intent comes from behavioral intent. Baker and Crompton in Chung-Hslen Lin (2012) explain that the revisit intention is the possibility of tourists to repeat the activity or return to a destination. There are two dimensions proposed by Baker and Crompton in Chung-Hslen Lin (2012), Intention to recommend (desire to recommend to others) and Intention to revisit (desire to return to visit).

In the previous research, as for the movement toward Halal certification, the manufacturing industries such as food, but a hotel and a restaurant whose customers are tourists, are only showing some interests. Movement of the 
logistics field is almost no at present. In this way, halal certification system in Japan has just begun, and the range is within a limited area of some service industries such as restaurant and so on. As for the possibility of commitment to halal to expand rapidly in the logistics field in Japan, it will be the case when importers give the manufacturers pressure and strong demand for logistics from shippers.

There is previous research about Halal tourism in Akita Japan. Akita Prefecture offers many attractions for Muslim tourists to explore such as World Heritage sites, natural scenic areas, distinct culture and tradition, unique festivals, nice food and climate. Some types of accommodation in Akita have experience and ready to cater Muslim tourists such as homestays in Semboku area. Nonetheless, hotels, restaurant and tour operators are still at early stage in welcoming Muslim tourists. As Muslim have specific rules to follow and to perform routine religious obligations wherever they are, tourism providers at host country should satisfy their needs.

\section{Research Methodology}

This research purpose is to measure the influence of the availability of Muslim-friendly facilities to Indonesian Muslim tourist to revisit Japan. Based on the framework above, the formulated hypothesis is: "Availability of Muslim friendly facilities have a significant positive effect to attract revisit intention of Indonesian Muslim tourists to Japan.

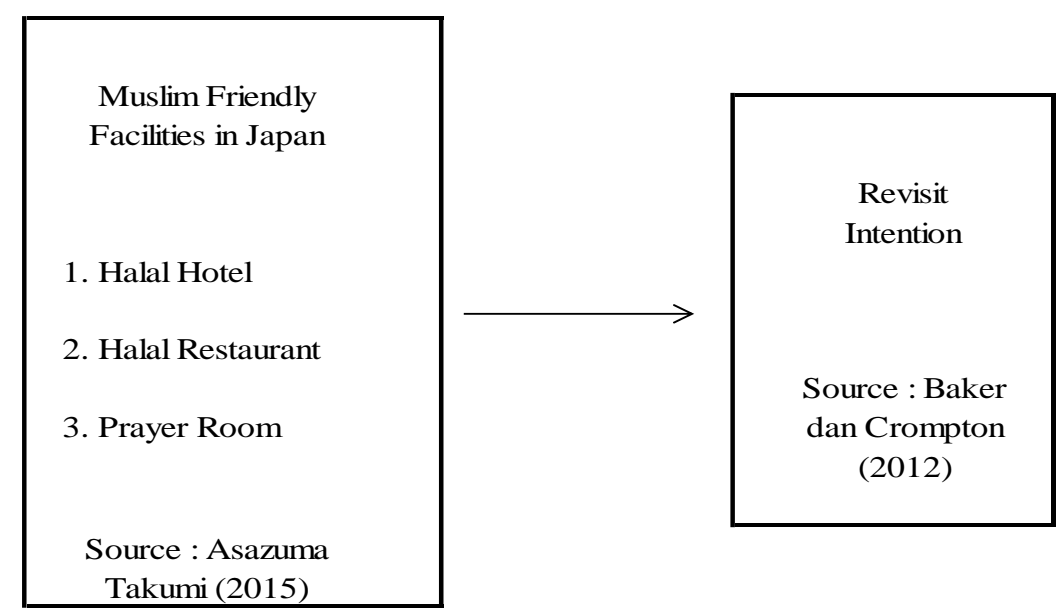

Picture 1. Framework

It is a descriptive research with quantitative and qualitative approaches. In this research, the population is Indonesian Muslim tourists who have been to Japan in the last 5 years. Sample is identified with accidental sampling technique. Based on the time limitation, the difficulties to calculate the number of 
Indonesian Muslim tourists who visit Japan, the researchers set a sample of 100 participants. Roscoe (1975) in Sekaran (2006) provides a general reference to determine sample sizes over 30 and less than 500 to be appropriate for most studies.

To see the relationship between the availability of a Muslim friendly facility consisting of a sharia hotel, a Halal restaurant, and prayer room and interpreting how powerful or influencing variables $\mathrm{X}$ are to variable $\mathrm{Y}$, the research is based on the proposed idea of Link, et all (2010: 454).

Regression analysis is employed to analyze the data. As for the research reliability, the test results for the questionnaire has a value of alpha 0.904 which means the items are in good reliability. The validity test shows that 30 questions are valid. Therefore no item is removed from the quetionnaires.

\section{Result and Discussion}

As the capital city, Tokyo is inhabited with 13 million population. Despite its size of only 0.6 percent of Japan's total, Tokyo also serves as the center of business, economics, politics, government and education. Many tourism destinations are located in the central areas of Tokyo such as Shibuya, Shinjuku, Akihabara and on the outskirts of Tokyo such as Yokohama and Chiba. Tokyo has typical Japanese gardens, shopping centers, museums, and Mount Fuji, the most famous mountain in Japan, is located just near the city center. According to the Halal in Japan website in Tokyo there are 222 restaurants and cafes that provide Halal or vegetarian menus that are safe for Muslim tourists. Besides 42 mosques are available at airports, malls, restaurants or settlements, and there are also 9 hotels that provide Muslim friendly facilities.

Another popular destination is Osaka with the third largest population in Japan and is located on Honshu Island. Water destinations, harbors, theme parks, and culinary are available here. Lots of tourists come to Osaka to visit Universal Studios Japan, Kaiyukan Aquarium and shopping destinations like Namba, Umeda, Amerikamura, Shinsaibashi and many more. No wonder Osaka is the center of port and industry. Osaka became an exciting metropolis to visit. According to the Halal in Japan website in Osaka there are 62 restaurants and cafes that provide halal or vegetarian menus that are safe for Muslim tourists, 12 mosques are situated at airports, malls, restaurants or settlements, and 24 hotels that provide Muslim-friendly facilities.

Kyoto is one of the favorite tourist destinations that should not be skipped in Japan. This old city has a lot of temples with a magnificent and beautiful building. According to the Halal in Japan website in Kyoto there are 39 restaurants and cafes that provide halal or vegetarian menus that are safe for Muslim tourists, 9 mosques are located at airports, malls, restaurants or settlements, and there are 9 hotels with Muslim-friendly facilities.

The questionnaires reveals the demografi data below. First of all, most of tourists are women with $67 \%$. Then, the majority of the tourist is in 21-30 years 
age range. As many as 55\% of the tourists are married. Regarding the education level, $62 \%$ of the tourists have bachelor degree. $41 \%$ of the tourist have average monthly income around IDR 5-10. The Muslim tourists are mostly private employees with 64\%. Most of the respondents comes from Jakarta and West Java, each achieves $40 \%$ result.

Other characteristics of the tourists are on the frequency of the trip, $49 \%$ are the first time visitor, while $45 \%$ are the repeat visitor with 2-4 times. As for the length of stay, the highest percentage (30\%) stays for 7-8 days. The travelmate can be friends $(29 \%)$, spouse $(22 \%)$ and family $(20 \%)$. The tourists get the information mostly from internet $(58 \%)$, and the accomodation is mostly 3 star hotel with $32 \%$. The most visited year is in $2016(42 \%)$

The significance of availability and ease of finding sharia hotels in Japan scores of 5497 which belong to a good category. It means that the availability of sharia hotels gets positive values for Indonesian Muslim tourists. Besides, the availability of halal restaurants in Japan score of 3439. This means that the availability and ease of finding halal restaurants get very positive value. The importance of availability of places of worship or prayer room in Japan scores 2918, it also shows a positive value for Indonesian Muslim tourists.

Despite the positive values for some aspects above, it is suprising that the availability of sharia hotels only score of 1283; a less favorable category. This negative value might be from the small number of sharia hotels. The availability of Halal restaurants in Japan gets positive response with 545 score. The availability of places of worship in Japan score 1095 indicating positive response. At present, places of worship in Japan can be found in airports, malls, or restaurants.

Based on data analysis with SPSS 16, the availability of Muslim friendly facilities consisting of sharia hotels, halal restaurants, and places of worship on the interest of return visit shows the value of $\mathrm{R}=0.456$. It indicates that the correlation between variables $\mathrm{X}$ with $\mathrm{Y}$ is 0.456 ,. While $\mathrm{R}$ square which is coefficient of determination, $\mathrm{R}$ square is 0,208 which means that influence from variable $\mathrm{X}$ to to variable $\mathrm{Y}$ mean equal to $20.8 \%$ while $79.2 \%$ come from other variables which are not discussed in this research.

The results shows that the availability of Muslim-friendly facilities has a significant positive impact on the interest of Indonesian Muslim tourists revisit to Japan. The analysis shows the value of $\mathrm{R}=0.456$ indicating correlation among variables $\mathrm{X}$ with $\mathrm{Y}$ is 0.456 . While $\mathrm{R}$ square which is coefficient of determination, $\mathrm{R}$ square is 0,208 which means that influence from variable $\mathrm{X}$ to to variable $\mathrm{Y}$ mean equal to $20.8 \%$ while other $79.2 \%$ come from variable or other factors not analyzed in this research.

The result of multiple regression test in this research are:

$$
\begin{aligned}
& \mathrm{Y}=\mathrm{a}+\mathrm{bX} 1+\mathrm{cX} 2+\mathrm{dX} 3 \\
& \mathrm{Y}=2.021+0.291 \mathrm{X} 1+0.191 \mathrm{X} 2+(-0.012) \mathrm{X} 3 \\
& \mathrm{Y}=2.021+0.291 \mathrm{X} 1+0.191 \mathrm{X} 2-0.012 \mathrm{X} 3
\end{aligned}
$$

TRJ Tourism Research Journal, Volume 1 (1), 2017 
The constant value of 2.021 in the regression equation above shows that income $\mathrm{Y}$ will remain at 2.021 without any influence of the independent variables. If the variable $\mathrm{X} 1$ increases by 1 unit, then the value of $\mathrm{Y}$ will increase by 0.291 . If the variable $\mathrm{X} 2$ increases by 1 unit, then the value of $\mathrm{Y}$ will increase by 0.191 . If the variable $\mathrm{X} 3$ increases by 1 unit, then the value of $\mathrm{Y}$ will decrease by 0,012 .

\section{E. Conclusion}

The availability of Muslim friendly facilities consisting of sharia hotels, halal restaurants, and places of worship have positive values for Indonesian Muslim tourists. Those facilities are essential in that every Muslim is obliged to consume halal food and perform daily prayer as it is the obligation of all Muslims including tourists who are traveling. While there are rules that make it easier for Muslims to combine prayer times and prayer places, Muslim travelers will be more comfortable to pray in clean and comfortable places, such as mosques or prayer rooms. Therefore the availability of prayer rooms in Japan is important as highlighted by the respondents. This research emphasizes that Indonesian Muslim tourists agree that the availability of Muslim-friendly facilities in Japan is important. In addition, the availability Halal food restaurants also scores very positive.

The research reveals that the availability of Muslim-friendly facilities in Japan has a mixed score. For example, the availability of sharia hotels in Japan has negative response. Halal website states the number of hotel with Muslim Friendly facilities is only 47. This means the number of hotels with Muslim facilities Friendly only reached $0.29 \%$ of the total accommodation available in Japan. Halal restaurants gets quite positive response. Halal restaurants can be found teither from brochures for Muslim tourists or from mobile applications. The availability of places of worship gains quite positive response. Halal guidebooks or apps for Muslim travelers help showing location of places of worship. This makes it easier for Muslim travelers to find places of worship in their location.

The Effect of variable $\mathrm{X}$ which is the availability of Muslim-friendly facilities consisting of sharia hotels, Halal restaurants, and prayer room against the variable $\mathrm{Y}$ which is the revisit intention is $20.8 \%$. The influence is not too large but still significant and has an influence to increase revisit intention of Indonesian Muslim tourist to Japan.

Sharia Tourism, Halal Tourism or Muslim Friendly Tourism is one of the fastest growing tourist attractions today. As country with the big muslim population, it is easier for Indonesia to adopt the concept of Halal tourism since more people know the rules in Islamic teachings, knowledge which is not understood by Japanese.

Despite the lack of Muslim-friendly facilities, Japan has succeeded in increasing Indonesian tourist arrivals. This might be due to the tourism attraction and accessibility with the flourishing of budget flights. Inspite of that, 
The Influence of Availability of Muslim Friendly Facilities towards Indonesian Muslim Tourist Revisit Intention to Japan

there should be some improvement on the accomodation to welcome more muslim travellers.

For further researcher, in-depth research can be undertaken to examine other factors that influence the interest of Indonesian tourists to revisit Japan. At the same time, Indonesia is hopefuly able to provide a better halal tourism to attract more foreign muslim travellers in the near future.

\section{F. Acknowledgment}

This research would never have been possible without the guidance from my professor, help from member of faculties of Trisakti School of Tourism, friends, and support from my family. I would like to express my deepest gratitude to my advisor, Dr. Myrza Ramhanita,M.Sc and Dr.Rahmat Ingkadijaya for their excellent guidance, caring, patience, and providing me with an excellent atmosphere for doing research. I would also like to thank Dr. Djoko Sudibyo, Dr. Himawan and Dr. Henky as my examiner during the thesis examination. Special thanks to the faculty members of Graduate Program Trisakti School of Tourism and batch 15 friends.

\section{REFERENCES}

Akyol, M. and Kilinc, O. (2014), "Internet and Halal Tourism Marketing", Electronic Turkish Studies; Volume 9/8.

Asazuma T. Halal industry activates Japanese tourism market. Cited from: http://human.kanagawa-u.ac.jp/gakkai/ student/ pdf / i11/ 110320.pdf

Assael, H. (1998). Consumer Behavior and Marketing Action 6 th edition. New York : International Thomson Publishing

Baker, D.A. and J.L. Crompton. (2000). Quality, satisfaction and behavioral intentions. Annals of Tourism Research. 27 (3). 785-804.

Battour, M., Ismail, M.N., \& Battor, M. (2011). The Impact of Destination Attributes on Muslim's Tourist's Choice, International Journal of Tourism Research, 13, 527-540

Chen, C.F. and Chen, FS. (2010). Experience quality, perceived value, satisfaction and behavioral intentions for heritage tourists. Journal of Tourism Management.

31. 29-35.

Crescent Rating. (2017). Global MuslimTravel Index 2017. Cited from: https://www.crescentrating.com/reports/mastercard-crescentratingglobal- muslim-travel-index-gmti-2017.html

Din, H. (1989). Islam and Tourism: Patterns, Issues, and Options, Annals of Tourism Research, 16, 542-563. 
The Influence of Availability of Muslim Friendly Facilities towards Indonesian Muslim Tourist Revisit Intention to Japan

Duman, T. (2011). Value of Islamic Tourism Offering: Perspectives from the Turkish Experience, World Islamic Tourism Forum, Seri Pacific Hotel, Kuala Lumpur, 12-13 July 2011.

Farahani, H.Z. \& Henderson, J.C. (2010). Islamic Tourism and Managing Tourism Development in Islamic Societies: The Cases of Iran and Saudi Arabia, International Journal of Tourism Research, 12, 79-89.

Hariani, D. (2016). Halal Japanese Culinary as Attraction for Muslim Travellers to Visit Japan. Advances in Economics, Business and Management Research, volume 28. Atlantis Press.

Islam, T., \& Chandra. (2013). Halal Marketing : Growing The Pie . International Journal of Management Research and Reviews, 3(12), 3938

Japan National Tourism Organization. (2017). Tourism statistics. Received from : http://www.jnto.go.jp/eng/ttp/sta/index.html

Kamirudin, Lina Munirah \& Hairul Nizam Ismail. (2014). Developing Framework of Muslim Tourists Typology from the Perspective of Pilgrimage. Universiti Teknologi Malaysia. Taken from: https://www.researchgate.net/_ publication /303805263_ Developing_Framework_of_Muslim_Tourists__ Typology_from_the_ Perspective_of_Pilgrimage_Tourism

Kuo, Chen - Tsai. (2011). Tourist Satisfaction and Intention to Revisit Sun Moon Lake.

Nor Zaid Md. Salleh . (2015). Final Report: Developing the non-Muslim tourist destination for Muslim tourists: A case study of Akita Prefecture, Japan. Taken from http://web.aiu. ac.jp/iasrc/wpcontent/uploads/2015/03/ final-report-Muslim-tourist-in-Akita.pdf

Riyad Eid and Hatem El-Gohary. MuslimTourist Perceived Value in the Hospitality and Tourism Industry.

Seongseop (Sam) Kim, Holly Hyunjung Im and Brian EM King. Muslim travelers in Asia: The destination preferences and brand perceptions of Malaysian tourists.

Songshan (Sam) Huang dan Cathy H.C. Hsu. (2009). Effect of Travel Motivation, Past Experience, Precevied Constraint, and Attitude on Revisit Intention

Sugiyono. (2014). Metode Penelitian Kuantitatif Kualitatif dan R\&D. Bandung : Alfabeta

Takayuki Mori. The present condition and the subject of Halal in Japan, In comparison with Malaysia. Taken from http://www. cai.ku. ac.th/Paper-SARD/paper34.pdf

Sekaran, U. (2006). Metodologi Penelitian untuk Bisnis, Edisi 4, Buku 1, Jakarta: Salemba Empat.

Zamani-Farahani, H., and Henderson, J.C. (2009). Islamic tourism and managing tourism development in Islamic societies: the cases of

TRJ Tourism Research Journal, Volume 1 (1), 2017 
The Influence of Availability of Muslim Friendly Facilities towards Indonesian Muslim Tourist Revisit Intention to Japan

Iran and Saudi Arabia. International Journal of Tourism Research 12 (1):79-89

TRJ Tourism Research Journal, Volume 1 (1), 2017 